\title{
Analysis of growth and light interception of balsam fir and white birch saplings following precommercial thinning
}

\author{
D Pothier *, A Margolis \\ Centre de Recherche en Biologie Forestière, Faculté de Foresterie et de Géomatique, \\ Université Laval, Ste-Foy, Québec, Canada G1K 7P4, (418) 656-7120
}

(Received 14 May 1990; accepted 15 January 1990)

\begin{abstract}
Summary - A precommercial thinning was conducted on young balsam fir (Abies balsamea (L) Mill) and white birch (Betula papyrifera Marsh) trees. Changes in light environment and growth response of the trees were followed during the next 2 growing seasons. The relative growth rate (RGR) of thinned balsam firs increased during both the first and the second growing season. This increase in growth was attributed to a greater net assimilation rate (NAR) which was associated with a higher level of light availability. Thinning tended to positively affect the RGR of white birch during the first summer following treatment but not during the second growing season. Similar fluctuations were noted for NAR even though light levels remained high for thinned white birch trees during both the first and the second growing season. Balsam fir produced more sapwood per unit of additional leaf area than controls during the first summer following treatment but no differences were observed during the second. The sapwood area growth to leaf area growth ratios of thinned and control white birches were similar during both the first and the second summer following thinning. Thus the sapwood area-leaf area relationship appears to be more stable following abrupt changes in environmental conditions for the indeterminate growth species, white birch, than for the determinate growth species, balsam fir.
\end{abstract}

growth analysis / thinning / net assimilation rate / light use efficiency / sapwood area-leaf area ratio

Résumé - Analyse de la croissance et de l'interception de la lumière du sapin baumier et du bouleau à papier à la sulte d'une éclaircie précommerciale. Une éclaircie précommerciale a été réalisée autour de jeunes tiges de sapin baumier (Abies balsamea (L) Mill) et de bouleau à papier (Betula papyrifera Marsh) et leur croissance de même que les changements de conditions lumineuses ont été étudiés pendant les deux saisons de croissance suivant le traitement. Le taux de croissance (RGR) des sapins baumiers éclaircis a augmenté pendant les 2 saisons de croissance suivant le traitement. Cette hausse de croissance a résulté d'une augmentation du taux d'assimilation net (NAR) qui a été associée à une plus grande disponibilité de la lumière. L'éclaircie a eu tendance à affecter positivement le RGR des bouleaux à papier pendant la première année suivant le traitement mais l'effet contraire a été observé pendant la deuxième année. Cette même tendance a aussi été observée pour le NAR quoique le niveau de lumière soit resté plus élevé pour les bouleaux

* Correspondence and reprints 
à papier éclaircis pendant la deuxième année suivant le traitement. Les sapins baumiers éclaircis ont produit plus d'aubier par unité de croissance en superficie foliaire que les témoins pendant le premier été suivant le traitement, mais aucune différence n'a été observée pendant le second été. La relation entre la croissance en superficie d'aubier et la croissance en superficie foliaire des bouleaux à papier dégagés a été semblable à celle des témoins pendant les 2 saisons de croissance suivant le traitement. II semble donc que, à la suite d'un changement des conditions environnementales, la relation entre la superficie d'aubier et la superficie foliaire des arbres soit plus stable dans le cas de l'espèce à croissance indéterminée, le bouleau à papier, que pour l'espèce à croissance déterminée, le sapin baumier.

analyse de croissance / éclaircie / taux d'assimllation net / efficacité d'utilisation de la lumière / relation superficle d'aubler-superficle foliaire

\section{INTRODUCTION}

Intra- and inter-specific competition in dense stands can limit the availability of environmental resources such as light, water, and mineral nutrients. Reducing competition through thinning is a common silvicultural practice which increases the supply of these environmental resources to selected crop trees. The increased light intensity is often associated with a higher transpiration rate on a unit leaf area basis (Black et al, 1980; Whitehead et al, 1984). Following thinning, this increased water loss per unit leaf area is normally compensated for by lower transpiration and rainfall interception rates per unit of ground area, often resulting in higher soil water content (Whitehead et al, 1984; Aussenac and Granier, 1988). Nevertheless, if little or no osmotic adjustment occurs, leaves of thinned trees can reach zero turgor, a symptom associated with thinning shock (Pothier and Margolis, 1990). Thinning can also increase the availability of mineral nutrients by reducing root competition if sprouting does not occur. Moreover, additional nutrients can be released by faster litter decomposition caused by the increase in temperature (Piene, 1978).

Light availability is usually the most important factor affecting tree growth following removal of competing vegetation
(Brand, 1986). This higher light intensity can modity leaf morphology by increasing the thickness of leaf mesophyll and the amount of chlorophyll per unit leaf area which can lead to increased photosynthetic rates (Nygren and Keliomäki, 1983; Oren et al, 1986). Higher photosynthetic rates per unit leaf area were thought to be responsible for the increased stemwood growth observed soon after thinning of Douglas fir (Brix, 1983). The contribution of net assimilation rate to the growth response began to decline $2 \mathrm{yr}$ after treatment, and was gradually replaced during subsequent years by the effect of increased foliage biomass (Brix, 1983).

The growth response of a tree following thinning is determined primarily by its photosynthetic capacity (Brix, 1983). Consequently, this study aims to examine the response of thinned trees in terms of foliage quantity, foliage efficiency and the relationship between sapwood area and leaf area. Since photosynthetic photon flux density (PPFD) was expected to be the major environmental component affecting tree growth, it was measured around sample trees and then integrated into the growth analysis. Two common competitors in the forests of eastern Canada, balsam fir (Abies balsamea (L) Mill), and white birch (Betula papyrifera Marsh) were selected for this study. 


\section{MATERIALS AND METHODS}

\section{Study area}

The study took place at Forêt Montmorency $\left(47.3^{\circ} \mathrm{N} 71.2^{\circ} \mathrm{W}\right)$ located $\approx 80 \mathrm{~km}$ north of Québec City, Québec, Canada. Mean annual precipitation is $\approx 1430 \mathrm{~mm}, \approx 66 \%(950 \mathrm{~mm})$ in the form of rain. The mean annual temperature is $0.3{ }^{\circ} \mathrm{C}$ with monthly averages ranging from -15.8 to $14.8{ }^{\circ} \mathrm{C}$ for January and July, respectively. The growing season typically extends from the beginning of June to the end of August.

A mixed balsam fir-white birch stand was selected for study. The stand, established from natural regeneration following a 1975 clearcut, was located on an east-facing exposure with a $12 \%$ slope. The soil was a well-drained humic orthic podzol derived from till. The stand contained $\approx 30000$ stems/ha in $1987, \approx 70 \%$ of which were white birch. At the beginning of the experiment, the average diameter at breast height and total height of balsam fir were $1.4 \mathrm{~cm}$ and $2.2 \mathrm{~m}$, respectively, while the values for white birch were $1.6 \mathrm{~cm}$ and $3.3 \mathrm{~m}$, respectively.

During the autumn of 1987,5 blocks were randomly established in the stand. Within each block, 6 balsam fir and 6 white birch trees were randomly selected. For 3 trees of each species, all trees within a distance of $1.5 \mathrm{~m}$ from a selected tree were cut down. The other 3 trees of each species were left as controls.

\section{Biomass measurements}

At the end of August in 1988 and 1989, 1 tree of each species-treatment combination was cut per block. The 20 trees (2 species $\times 2$ treatments $\times$ 5 blocks) were divided by height into 3 crown sections, placed in separate plastic bags, and stored in a refrigerator.

For each crown section, all current year shoots and leaves were removed and their fresh weights were determined. Subsamples of $\approx \mathbf{3 0}$ balsam fir needles and 5 white birch leaves were then collected, and leaf areas were measured with a leaf area meter (Model Li-3000, LiCor Ltd, Lincoln, NE, USA). These subsamples, and all remaining leaves, were dried at $70^{\circ} \mathrm{C}$ for at least $48 \mathrm{~h}$. Shoot subsamples were also dried for the determination of fresh weight-dry weight conversion factors. The same procedure was used for balsam fir shoots and needles of the previous growing season. Leaves, shoots and stems from the rest of the crown section were weighed separately and another set of subsamples was taken for determination of fresh weight-dry weight conversion factors. Furthermore, the basal area growth for 1988 and 1989 was calculated for each of the 3 crown sections and its percentage in relation to the total basal area was calculated. This factor was applied to the total biomass of the stem and branches of each crown section in order to estimate stem and branch growth for each of the 2 years.

\section{Light measurements}

On 5 cloudless days during each growing season, the percentage of photosynthetic photon flux density (PPFD) reaching each sample tree was estimated using a $\mathrm{Li}$-Cor quantum sensor (Li-190SB, Li-Cor Ltd, Lincoln, NE, USA). The quantum sensor, which was connected to an integrating millivoltmeter, was uniformly scanned up and down and from side to side of the sunfacing side of each sample tree for $\approx 20 \mathrm{~s}$. Just prior to each of these measurements, another integrated measure of PPFD was taken in an opening under full sun. By dividing these 2 values, we were able to assess the percentage of PPFD reaching our study trees. Photosynthetic photon flux density measurements were taken at randomly selected times between 9:00 and 15:00 for each tree. Thus, these PPFD measurements represent average values from the main part of the day and do not include any measurements taken when the sun was near the horizon.

The total incident PPFD for each growing season (June 1-August 31) was estimated from a Bellani pyranometer located in an opening near the experimental site. The daily readings of the Bellani pyranometer were corrected for changes in temperature and then transformed into net short-wave radiation $(150-4000 \mathrm{~nm})$ using the equation of Bernier and Plamondon (1983). Total PPFD was calculated assuming that $50 \%$ of the net short-wave radiation lay within the waveband $400-700 \mathrm{~nm}$ (Hunt et al, 1984). 
The product of incident PPFD for each growing season and the percentage of PPFD available to the trees was taken as an estimate of light availability $\left(I_{\alpha}\right)$ for each sample tree. Moreover, the amount of PPFD intercepted by trees $(J)$ was estimated by the product of $l_{o}$ times the projected leaf area of each tree (Hunt et al, 1984).

\section{Growth analysis}

Growth analysis was performed using the relative growth rate (RGR) and its classical subdivision into specific leaf area (SLA), leaf weight ratio (LWR), and net assimilation rate (NAR):

$$
\text { [1] } \begin{aligned}
R G R & =\frac{1}{W} \frac{\partial W}{\partial t}=\frac{L A}{L W} \times \frac{L W}{W} \times \frac{1}{L A} \frac{\partial W}{\partial t} \\
& =S L A \times L W R \times N A R
\end{aligned}
$$

where $W$ is the total dry mass of stemwood and branches $(g), L A$ is the projected leaf area of the tree $\left(\mathrm{m}^{2}\right), L W$ is the leaf weight of the tree (g), and $\partial W / \partial t$ is the instantaneous rate of change in plant dry mass. The calculations of $R G R, S L A, \angle W R$, and NAR were made according to Margolis and Brand (1990).

These calculations used estimates of $L A$ of the previous growing season because direct measurements would have required defoliating the trees at the beginning of the experiment. For balsam fir, projected leaf area of the previous year was assessed by subtracting the current year leaf area production from the total leaf area adjusted to account for the $12.5 \%$ turnover of balsam fir foliage per year (Bakusis and Hansen, 1965). The same procedure was applied for the determination of the previous year leaf weight. For white birch, the previous year leaf area was estimated from the sapwood area to leaf area ratios determined for the current year leaf area and subtracting the current year sapwood growth. Previous growing season leaf weight for white birch was computed as the product of the previous year leaf area and the specific leaf weight $\left(\mathrm{g} / \mathrm{m}^{2}\right)$ of the control white birches only.

Net assimilation rate (NAR) was further subdivided into light availability and light use efficiency (Margolis and Brand, 1990):
[2] $N A R=\frac{1}{L A} \frac{\partial W}{\partial t} \approx \frac{J}{L A} \times \frac{1}{J} \frac{\partial W}{\partial t}=l_{0} \times L U E$

where $J$ is the amount of PPFD energy intercepted by a plant per unit time $\left(\mathrm{MJ} \mathrm{yr}^{-1}\right)$. Thus, $I_{0}$ corresponds to the light availability, ie the amount of incident light per unit area per unit time (MJ m-2 $\left.\mathrm{yr}^{-1}\right)$, and LUE is the light use efficiency ie the amount of wood (g dry weight) produced per unit of intercepted light $\left(\mathrm{g} \mathrm{MJ}^{-1}\right)$. Since $R G R, N A R$ and $L U E$ are average values over periods of $1 \mathrm{yr}$, the product of SLA x LWR $\mathrm{x}$ NAR (Eq 1) and $l_{0} \times$ LUE (Eq 2) only approximate $R G R$ and NAR, respectively. These products will equal $R G R$ and NAR only if the values are calculated instantaneously (Radford, 1967). Since the values shown in tables I and II are yearly averages, multiplying these average values together does not necessarily give the same result that one would expect from the equations. In fact, fairly large discrepancies did occur.

\section{Statistical analysis}

Data were subjected to analyses of variance for a split-plot design where species was the main plot, and the thinning treatment was the split plot. Least significant differences at the $95 \%$ level were computed using the Waller-Duncan multiple comparison test. Logarithmic data transformation was applied when the variances of groups were found to be proportional to their means.

\section{RESULTS}

Precommercial thinning increased $R G R$ of balsam fir by $43 \%$ the first growing season following treatment and $65 \%$ the second growing season (table I). Thinning did not significantly affect $L W R$ of balsam fir but rather resulted in a decreased $S L A$. Net assimilation rate (NAR) was increased $78 \%$ and $92 \%$ by the treatment during the first and the second growing seasons following thinning, respectively (table l). Thus, for a given amount of leaf area, thinned balsam fir produced more wood 
Table I. Relative growth rate (RGR) and its partitioning into specific leaf area (SLA), leaf weight ratio (LWR), net assimilation rate (NAR), light availability (IO), and light use efficiency (LUE) for control and thinned balsam fir 1 and 2 growing seasons following treatment.

\begin{tabular}{|c|c|c|c|c|}
\hline & \multicolumn{2}{|c|}{ First growing season } & \multicolumn{2}{|c|}{ Second growing season } \\
\hline & Control & Thinned & Control & Thinned \\
\hline $\begin{array}{l}\text { RGR }\left(\mathrm{g} \mathrm{g}^{-1} \mathrm{yr}^{-1}\right) \\
\text { SLA }\left(10^{-4} \mathrm{~m}^{2} / \mathrm{g}\right) \\
\text { LWR }(\mathrm{g} / \mathrm{g}) \\
\text { NAR }\left(\mathrm{g} \mathrm{m}^{-2} \mathrm{yr}^{-1}\right) \\
I_{o}\left(\mathrm{MJ} \mathrm{m} \mathrm{m}^{-2} \mathrm{yr}^{-1}\right) \\
\text { LUE }(\mathrm{g} / \mathrm{MJ})\end{array}$ & $\begin{array}{l}0.42 \pm 0.13^{b c} \\
69 \pm 3^{a} \\
0.47 \pm 0.12^{a} \\
137 \pm 14^{b} \\
112 \pm 58^{c} \\
1.69 \pm 1.29 a\end{array}$ & $\begin{array}{c}0.60 \pm 0.14^{a} \\
63 \pm 3^{b} \\
0.43 \pm 0.07^{a} \\
244 \pm 49^{a} \\
583 \pm 122^{a} \\
0.43 \pm 0.16^{b c}\end{array}$ & $\begin{array}{c}0.34 \pm 0.04^{c} \\
58 \pm 6^{b} \\
0.48 \pm 0.06^{a} \\
132 \pm 9^{b} \\
330 \pm 286^{b} \\
1.08 \pm 1.51^{a b}\end{array}$ & $\begin{array}{l}0.56 \pm 0.13^{a b} \\
48 \pm 6^{c} \\
0.50 \pm 0.11^{a} \\
254 \pm 49^{a} \\
736 \pm 61^{a} \\
0.19 \pm 0.05^{c}\end{array}$ \\
\hline
\end{tabular}

NB: these values were computed according to Margolis and Brand (1990). Each value is the mean ( $\pm S E$ ) of 5 measurements. Values within a horizontal row followed by different letters are significantly differen $(P<0.05)$.

than controls. The increase in NAR was associated with higher light availability $I_{0}$ (table I), whereas light use efficiency (LUE) was inversely related to $I_{0}$ (fig 1 ).

The overall effect of the thinning on the growth rate of white birch was less clear (table II). Whereas the NAR increased significantly the first season, the compensating decrease in SLA resulted in no significant differences between RGRs. During the second growing season, however, the $L W R$ of the thinned birches increased significantly but NAR was no longer statistically significant and thinned trees even showed a tendency toward a lower NAR than the controls. The increase in the $L W R$ was compensated for by a decrease in the $S L A$ and thus the RGR of thinned and control birches showed no significant differences (table II).

Table II. Relative growth rate $(R G R)$ and its partitioning into specific leaf area $(S L A)$, leaf area ratio (LWR), net assimilation rate (NAR), light availability $\left(l_{o}\right)$, and light use efficiency (LUE) for control and thinned white birch 1 and 2 growing seasons following treatment.

\begin{tabular}{cccc}
\multicolumn{2}{c}{ First growing season } & & \multicolumn{2}{c}{ Second growing season } \\
Control & Thinned & & Control Thinned
\end{tabular}

\begin{tabular}{|c|c|c|c|c|}
\hline $\begin{array}{l}R G R\left(\mathrm{~g} \mathrm{~g}^{-1} \mathrm{yr}^{-1}\right) \\
S L A\left(10^{-4} \mathrm{~m}^{2 / a}\right)\end{array}$ & $\begin{array}{l}0.25 \pm 0.11^{a} \\
174+12 a\end{array}$ & $\begin{array}{l}0.35 \pm 0.06^{a} \\
150+5 b\end{array}$ & $0.29 \pm 0.12^{a}$ & $0.21 \pm 0.06^{a}$ \\
\hline$L W R(g / g)$ & $0.11 \pm 0.03^{b}$ & $0.08 \pm 0.03^{b}$ & $0.11 \pm 0.02^{b}$ & $0.16 \pm 0.05^{a}$ \\
\hline$N A R\left(\mathrm{~g} \mathrm{~m}^{-2} \mathrm{yr}^{-1}\right)$ & $137 \pm 74^{b}$ & $355 \pm 192^{a}$ & $150 \pm 66^{b}$ & $108 \pm 40^{b}$ \\
\hline$I_{o}\left(\mathrm{MJ} \mathrm{m}^{-2} \mathrm{yr}^{-1}\right)$ & $77 \pm 28^{b}$ & $672 \pm 61^{a}$ & $84 \pm 36^{b}$ & $668 \pm 128^{a}$ \\
\hline$L U E(\mathrm{~g} / \mathrm{MJ})$ & $1.83 \pm 0.92^{a}$ & $0.50 \pm 0.23^{b}$ & $1.40 \pm 0.55^{a b}$ & $0.20 \pm 0.08 \mathrm{c}$ \\
\hline
\end{tabular}

$N B$ : these values were computed according to Margolis and Brand (1990). Each value is the mean ( $\pm S E$ ) of 5 measurements. Values within a horizontal row followed by different letters are significantly different $(P<0.05)$. 


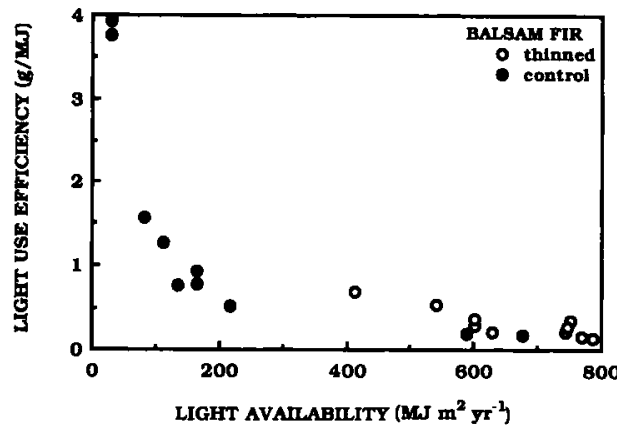

Fig 1. Relation between light use efficiency and light availability of thinned and control balsam fir trees.

Thinning did not affect the relative height growth rate of either species (table III). The diameter growth rate of balsam fir was stimulated by thinning for both years of growth, but no statistical differences were detected for white birch (table III).
The sapwood area-leaf area ratio of neither balsam fir nor white birch differed between treatments (table III). However, the slope of the sapwood area growth-leaf area growth relation of thinned balsam firs was different from that of controls $(P<$ $0.10)$ during the first year following treatment (fig 2). During this first summer, thinned balsam firs tended to produce more sapwood area per amount of leaf area growth than did control trees. During the second year following thinning, however, both treated and control balsam fir trees had similar slopes for the sapwood area growth to leaf area growth relationship (fig 2). On the other hand, thinning did not significantly affect the sapwood area growth to leaf area growth relationship of white birch during either the first or the second growing season (fig 3) even though there was a significant increase in $L W R$ for thinned trees 2 yr after treatment (table II).

Table III. Relative diameter growth rate (RDGR, relative height growth rate (RHGR) and sapwood area-leaf (SALA) ratios of control and thinned trees one and two growing seasons foliowing precommercial thinning.

\begin{tabular}{|c|c|c|c|c|}
\hline & \multicolumn{2}{|c|}{ First growing season } & \multicolumn{2}{|c|}{ Second growing season } \\
\hline & Control & Thinned & Control & Thinned \\
\hline \multicolumn{5}{|c|}{$R D G R\left(\mathrm{~cm} \mathrm{~cm}^{-1} \mathrm{yr}^{-1}\right)$} \\
\hline $\begin{array}{l}\text { Balsam fir } \\
\text { White birch }\end{array}$ & $\begin{array}{l}0.17 \pm 0.06^{b c} \\
0.08 \pm 0.03^{a}\end{array}$ & $\begin{array}{l}0.25 \pm 0.07^{\mathrm{a}} \\
0.13 \pm 0.02^{\mathrm{a}}\end{array}$ & $\begin{array}{l}0.12 \pm 0.03^{c} \\
0.11 \pm 0.05^{a}\end{array}$ & $\begin{array}{l}0.21 \pm 0.05^{\mathrm{ab}} \\
0.07 \pm 0.03^{\mathrm{a}}\end{array}$ \\
\hline \multicolumn{5}{|c|}{$R H G R\left(\mathrm{~cm} \mathrm{~cm}^{-1} \mathrm{yr}^{-1}\right)$} \\
\hline $\begin{array}{l}\text { Balsam fir } \\
\text { White birch }\end{array}$ & $\begin{array}{l}0.13 \pm 0.05^{a} \\
0.09 \pm 0.04^{a}\end{array}$ & $\begin{array}{l}0.12 \pm 0.04^{a} \\
0.04 \pm 0.02^{a}\end{array}$ & $\begin{array}{l}0.11 \pm 0.02^{a} \\
0.08 \pm 0.06^{a}\end{array}$ & $\begin{array}{l}0.13 \pm 0.05^{a} \\
0.05 \pm 0.03^{a}\end{array}$ \\
\hline \multicolumn{5}{|c|}{$S A L A$ ratios $\left(\mathrm{cm}^{2} / \mathrm{m}^{2}\right)$} \\
\hline $\begin{array}{l}\text { Balsam fir } \\
\text { White birch }\end{array}$ & $\begin{array}{l}2.66 \pm 0.42^{\mathrm{a}} \\
5.01 \pm 1.42^{\mathrm{a}}\end{array}$ & $\begin{array}{l}3.00 \pm 0.71^{a} \\
7.76 \pm 4.42^{a}\end{array}$ & $\begin{array}{l}4.99 \pm 2.02^{\mathrm{a}} \\
5.06 \pm 1.17^{\mathrm{a}}\end{array}$ & $\begin{array}{l}4.44 \pm 0.78^{a} \\
4.08 \pm 1.07^{a}\end{array}$ \\
\hline
\end{tabular}

NB: each value is the mean ( $\pm S E$ ) of 5 measurements. Values within a horizontal row followed by different letters are significantly differetn $(P<0.05)$. 


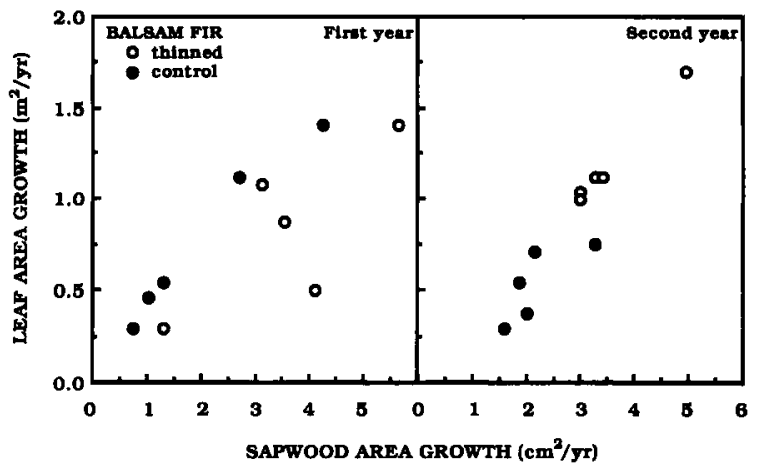

Fig 2. Relation between leaf area growth and sapwood area growth of thinned and control balsam fir trees, one and two growing seasons following thinning.

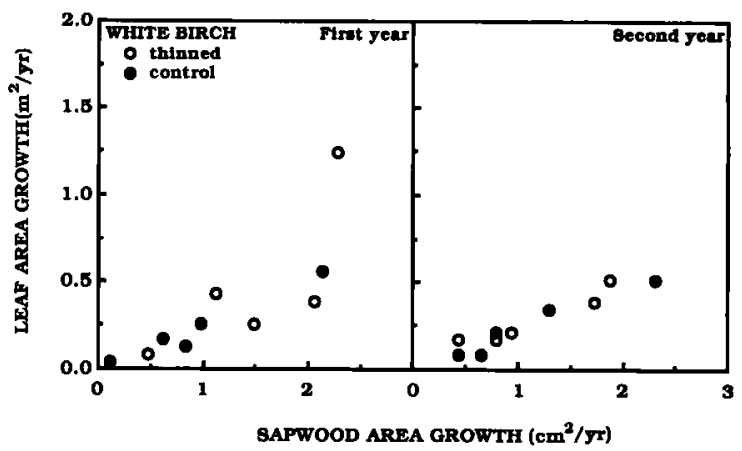

Fig 3. Relation between leaf area growth and sapwood area growth of thinned and control white birch trees one and two growing seasons following thinning.

\section{DISCUSSION}

The relative growth rate of thinned balsam fir was increased during both the first and the second growing seasons following treatment (table I). On the other hand, the ratio of photosynthetic to nonphotosynthetic tissues (LWR) was not affected by treatment (table I). Neither were there any significant differences in total leaf area between treatments during either of the 2 growing seasons. Consequently, the improvement in growth of balsam fir following thinning can be attributed to leaves which have a higher efficiency for producing wood, ie trees with a higher NAR.

Net assimilation rate can be partitioned into light availability and light use efficiency (Eq 2). The thinning increased $I_{0}$ of balsam fir $420 \%$ and $123 \%$ during the first and the second growing seasons following treatment, respectively (table I). These increas- 
es in $I_{o}$ probably increased phototsynthetic rates by increasing the period of time that leaves were ligth-saturated as well as increasing PPFD levels when leaves were not light-saturated.

Another way in which NAR can be increased is by increasing the efficiency of transforming a given unit of light into wood. This would be seen as an increased LUE at a given value of $I_{0}$. Although the maximum photosynthetic rate per unit leaf area can be increased with increasing light levels, it is normally reached below $50 \%$ of full sunlight for temperate tree species of small size (Leverenz and Jarvis, 1979; Nygren and Kellomäki, 1983). Since the thinning increased PPFD beyond $80 \%$ of full sunlight, a significant part of this energy was probably not used by the leaves for photosynthesis because factors other than light availability became limiting. This would explain the curvilinear nature of the relation between $L U E$ and $I_{o}$ (fig 1 ) as well as the lower LUE values calculated for thinned trees in comparison to controls (table I).

Thinning tended to positively affect $R G R$ of white birch during the first summer following treatment whereas the reverse effect was observed during the second (table II). Similar fluctuations were noted in NAR (table II). The decreased $R G R$ and $N A R$ of the thinned white birch during the second growing season was accompanied by similar trends in diameter and height growth rates (table III). Such growth responses after thinning are often referred to as thinning shock (Harrington and Reukema, 1983). However, the thinned white birches were still able to respond to treatment by decreasing SLA during both summers (table II) and this suggests that their leaves were still more photosynthetically active than controls (Nygren and Kellomäki, 1983; Oren et al, 1986). An increase in the ailocation of photosynthates to leaf production (table II), to root production, to respiration or to storage are possible reasons for the low above-ground stemwood growth of the thinned white birches during the second summer after treatment.

During the first summer following treatment, thinned balsam firs produced more sapwood per unit of additional leaf area than controls (fig 2). This situation probably occurred because the determinate growth habit of balsam fir placed restrictions on the number of foliage elements and thus on the potential leaf area growth whereas cambial growth was not restricted (Lanner, 1985). Consequently, thinned and control balsam firs produced similar increases in leaf area during the first growing season whereas the thinning increased sapwood area growth relative to controls. This led to differences in the sapwood area growth to leaf area growth relationship (fig 2). As proposed by Jarvis (1975), a higher sapwood area growth to leaf area growth ratio following thinning could potentially reduce the resistance to water flow from roots to leaves and thus help trees acclimate to a higher rate of transpiration.

Thinned and control balsam fir no longer showed different sapwood area growth to leaf area growth ratios during the second growing season following treatment (fig 2). This can be explained by the increased leaf area growth of thinned trees due to favorable light conditions during bud formation in the first growing season following the treatment. Since both sapwood area growth and leaf area growth were stimulated by the treatment during this second summer, the relation between them for thinned trees equilibrated with that of the controls (fig 2).

The sapwood area growth to leaf area growth ratio of thinned and control white birches were similar during both the first and the second growing seasons following 
thinning (fig 3). Thus the sapwood arealeaf area relationship appeared to be more stable following abrupt changes in environmental conditions for white birch than for balsam fir. This faster adjustment of white birch following new environmental conditions is most likely due to its indeterminate growth habit.

The morphological differences between balsam fir and white birch have been shown to influence their physiological response to precommercial thinning. Pothier and Margolis (1990) demonstrated that the deciduous habit of white birch versus the evergreen habit of balsam fir can affect leaf water relations following thinning. They also demonstrated that differences in the wood anatomy of the 2 species (ie vessels versus tracheids) permitted the main stem of white birch to maintain a sapwood permeability $\approx 2$ times greater than that of balsam fir (Pothier and Margolis, 1990). Assuming similar differences in the resistance to water flow through minor branches, white birch would be able to maintain a transpiration rate nearly 2 times greater than balsam fir for the same leaf water potential. The results reported in this current paper show that balsam fir responded to thinning with greater NAR during both the first and the second growing seasons following treatment while white birch responded with a greater NAR the first year and a greater $L W R$ the second year. Finally, we suggest that the indeterminate growth habit of white birch permitted it to reestablish an equilibrium between sapwood area growth and leaf area growth more rapidly than did the determinate growth species balsam fir.

\section{ACKNOWLEDGMENTS}

We thank $Y$ Gagnon, J Bernier and E Pothier for assistance in the field and the laboratory and $T$ Hinckley and one anonymous reviewer for their helpful comments on the manuscript. This research was supported by Natural Science and Engineering Research Council of Canada and the US National Science Foundation.

\section{REFERENCES}

Aussenac G, Granier A (1988) Effects of thinning on water stress and growth in Douglas fir. Can J For Res 18, 100-105

Bakuzis EV, Hansen HL (1965) Balsam fir Abies balsamea (L) Mill. A Monographic Review. The University of Minnesota Press, Minneapolis, USA

Bernier PY, Plamondon AP (1983) Estimating net short-wave radiation with the Bellani pyranometer. Agric Meteorol 30, 175-184

Black TA, Tan CS, Nnyamah JU (1980) Transpiration rate of Douglas fir trees in thinned and unthinned stands. Can J Soil Sci 60, 625-631

Brand DG (1986) Competition-induced changes in developmental features of planted Douglas fir in southwestern British Columbia. Can $J$ For Res 16, 191-196

Brix $H$ (1983) Effects of thinning and nitrogen fertilization on growth of Douglas fir: relative contribution of foliage quantity and efficiency. Can J For Res 13, 167-175

Harrington CA, Reukema DL (1983) Initial shock and long-term stand development following thinning in a Douglas fir plantation. For Sci $29,33-46$

Hunt R, Warren Wilson J, Hand DW, Sweeney DG (1984) Integrated analysis of growth and light interception in winter lettuce 1. Analytical methods and environmental influences. Ann Bot 54, 743-757

Jarvis PJ (1975) Water transfer in plants. In: Heat and Mass Transfer in the Biosphere (Afgan $\mathrm{NH}, \mathrm{De}$ Vries, eds) John Wiley and Sons, NY, 369-394

Lanner RM (1985) On the insensitivity of height growth to spacing. For Ecol Manage 13, 143148

Leverenz JW, Jarvis PG (1979) Photosynthesis in Sitka spruce. VIII. The effects of light flux density and direction on the rate of net photosynthesis and the stomatal conductance of needles. J App/ Ecol 16, 919-932 
Margolis HA, Brand DG (1990) An ecophysiological basis for understanding plantation establishment. Can J For Res 20, 375-390

Nygren M, Kellomäki S (1983) Effect of shading on leaf structure and photosynthesis in young birches Betula pendula Roth and $B$ pubescens Ehrh. For Ecol Manage 7, 119132

Oren R, Schluze ED, Zimmermann R (1986) Estimating photosynthetic rate and annual carbon gain in conifers from specific leaf weight and leaf biomass. Oecologia 70, 187-193

Piene $H$ (1978) Effects of increased spacing on carbon mineralization rates and temperature in a stand of young balsam fir. Can J For Res 8, 398-406

Pothier D, Margolis HA (1990) Changes in the water relations of balsam fir and white birch saplings after thinning. Tree Physiol 6, 371380

Radford PJ (1967) Growth analysis formulae their use and abuse. Crop Sci 7, 171-175

Whitehead D, Jarvis PG, Waring RH (1984) Stomatal conductance, transpiration, and resistance to water uptake in a Pinus sylvestris spacing experiment. Can J For Res 14, 692700 